\title{
Salmonella spp Lignieres 1900 (Enterobacteriales: Enterobacteriaceae) IN Informally Sold Broilers
}

\section{Ludmilla Santana Soares e Barros*; João Guilherme Nobre Ribeiro**; Jaqueline Batista Caselli****}

\begin{abstract}
Brazil is one of the largest producers and exporters of poultry. Although the growth of the poultry industry provided a source of high protein rates, the intensive rearing of poultry with its exponential increase with more birds per square meter, favored the installation and multiplication of pathogens such as Salmonella that has become a great concern in the poultry industry. There are numberless independent firms and poultry producers in the state of Bahia, Brazil, that sell live chicken to meet demands of establishments that sell birds hailing from illegal abattoirs. A study was conducted in carcasses collected from six different establishments, during ten weeks, in the city of Feira de Santana BA Brazil, totaling up to 60 samples, to evaluate the occurrence of Salmonella in broilers. Results show a $28.3 \%$ occurrence of the pathogen. The above situation is a general warning on the great risk to which consumers may be exposed. It should also be underscored that the broilers were slaughtered and processed in poor sanitary and hygienic standards with total disregard to current legislation.
\end{abstract}

Keywords: Poultry, Salmonella, illegal slaughter

* Center for Agricultural, Environmental and Biological Sciences (CCAAB) of the Federal University of Reconcavo of Bahia (UFRB), Rua Rui Barbosa, 710, Centro, CEP 44380-000, Cruz das Almas, Bahia, Brazil. Author for correspondence: barros@ufrb.edu.br

**Veterinarian, the Career Masters in Agricultural Protection - UFRB, Cruz das Almas, Bahia, Brazil.

***Veterinary Medical - Food Microbiology Laboratory, Av Mr Luís Eduardo Magalhães, KM 99, Part 1, CEP: 44079-002 Feira de Santana, Bahia Brazil.

Submetido em 12.10.2014; Aceito em 15. 12. 2014 


\section{Introduction}

Salmonellae are widely distributed in nature and are capable of infecting both humans and animals. Poultry infected by paratyphus salmonellae may develop the disease either clinically or asymptomatically by harboring the agents and becoming potential sources of salmonellosis for humans (NAGARAJA et al. 1991, BARROW, 1993; SANTOS et al., 2000).

From the 1980s henceforth food toxic-infections caused by Salmonella increased and Rodrigues et al. (1990) and Santos et al. (2000) attribute this fact to intake of eggs and other sub-products contaminated by Salmonella enterica .

However, Salmonella in broilers' carcasses should never be discarded (RAMPLING et al. 1989, BOER and ZEE 1992, GIESSEN et al. 1992, POPPE, 1994, SCUDERI et al. 1996, COSTA, 1996, SAKAI \& CHALERMCHAIKIT, 1996,
WARD and THRELFALL, 1997; SANTOS et al., 2000).

Chicken meat in England and Wales caused outbreaks and sporadic cases of the disease (Rampling et al. 1989; Santos et al., 2000), with approximately 30,000 cases of food toxic-infections in humans (WARD \& THRELFALL, 1997; SANTOS et al., 2000).

Tavechio et al. (1996) reported an increase in the isolation of Salmonella enterica in Brazil as from 1993. Between 1991 and 1994 Italy experienced 1699 food-caused outbreaks, with Salmonella causing $81 \%$ of which $34 \%$ were of Salmonella enterica (SCUDERI et al. 1996; SANTOS et al., 2000).

Animal-originating products, especially from poultry, are an important source of human protein. In the Brazilian retail market, cooled or frozen poultry carcasses are available, even though cooling fails to eliminate bacteria as those of the genus Salmonella (SANTOS et al., 
2000).

Scarcity of analysis on this subject is a highly notorious fact in Northeastern Brazil where a fast development in poultry industries is currently occurring. New researches on the occurrence of Salmonella spp. in the poultry chain of this region are urgently required. Further, regional differences that affect the development of these micro-organisms should also be taken into account.

Current assay investigates the occurrence of Salmonella spp. in several food establishments in Feira de Santana BA Brazil, which exhibits the 'hot chicken' commercialization.

Results in current analysis may contribute towards the identification and introduction of more specific and effective control measures directed towards local specificities. Greater visibility will also be established with regard to the risks that the population and consumers undergo by providing the controlling authorities with highly useful microbiological data.

\section{Materials and Methods}

Current assay was performed in Feira de Santana BA Brazil, a city in the centralnorth meso-region of the state of Bahia, Brazil. The method comprised the collection of samples of poultry carcasses from illegal abattoirs.

The carcasses were bought from several commercial firms in one of the city districts. The methodology included certain advantages such as low cost, easiness in collecting the material and microbiological analyses developed without any further costs.

Six firms, called A, B, C, D, E and F, which sell broiler carcasses directly from the illegal abattoir, were chosen at random. A sampling plan was established by which seventy samples were analyzed. Carcasses from each firm were collected weekly, in the morning, during 10 weeks, between September and October 2013.

Internal temperature was measured at the carcass's thermal center, or rather, at 
the supracoracoid region and pectoral muscles. Data were collected by a portable thermometer immediately after the collection of the carcasses and on the same premises. Samples were then conditioned in an isothermal container and sent to the Laboratory of Food and Water Microbiology of a food-processing industry in the city.

The samples were collected in the morning and the material was sent to the microbiology laboratory for the analysis of Salmonella spp immediately after collection. Analysis was based on the methodology following Norm 62 by MAPA (BRASIL, 2003). Samples had the same visual standard, characterized by a yellowish color, with wrapped offal placed within the celomatic cavity of the carcass.

Results were given following proposal in the two-class sampling plan, or rather, when the sample could be acceptable or not (BRASIL, 2001). The plan was applied in the Salmonella research due to the bacterium's

epidemiological characteristics.

A long thermometer (stainless steel rod, $120 \mathrm{~mm}$ long and scale ranging between $-50^{\circ} \mathrm{C}$ and $200^{\circ} \mathrm{C}$ ) verified the temperature of each carcass on the collection site. Temperature was taken in the pectoralis maior muscle with the thermometer rod penetrating some $4 \mathrm{~cm}$ in the region. Room temperature of the premises where collection was performed was also measured.

\section{Results and Discussion}

Ten samples from each firm were evaluated during 10 weeks (a sample collected per week) in August, September and October 2013. Results for research on Salmonella for each firm are given, coupled to the temperature at collection.

Tables 1, 2 ,3, 4, 5 and 6 show frequencies for each firm, with firms A, B and $\mathrm{C}$ demonstrating critical results due to 
their high positive frequency. Firms $\mathrm{E}$ and between the start and end of the F showed similar frequencies, with lower investigation.

rates than the others. On the other hand, Table 7 provides results for positive firm D failed to show any positive samples of Salmonella during the whole frequency for the pathogen under analysis, assay.

Table 1. Results of microbiological analyses and temperature, per week, at firm A. Feira de Santana, BA, Brazil, 2014.

\begin{tabular}{cccc}
\hline Week & $\begin{array}{c}\text { Number of positive } \\
\text { samples }\end{array}$ & $\begin{array}{c}\text { Frequency } \\
(\%)\end{array}$ & $\begin{array}{c}\text { Temperature } \\
\text { of carcass }\left({ }^{\mathbf{O}} \mathbf{C}\right)\end{array}$ \\
\hline $\mathbf{1}$ & 0 & 0 & 35.9 \\
$\mathbf{3}$ & 1 & 10 & 37.7 \\
$\mathbf{4}$ & 0 & 0 & 34.7 \\
$\mathbf{5}$ & 0 & 0 & 37.8 \\
$\mathbf{6}$ & 1 & 10 & 32.7 \\
$\mathbf{7}$ & 1 & 10 & 33.4 \\
$\mathbf{8}$ & 1 & 10 & 32.6 \\
$\mathbf{9}$ & 0 & 0 & 36 \\
$\mathbf{1 0}$ & 1 & 10 & 34.4 \\
$\mathbf{T}$ & $\mathbf{6}$ & $\mathbf{6 0}$ & $36^{\circ} \mathrm{C}(\mathrm{mean})$ \\
\hline
\end{tabular}


Table 2. Results of microbiological analyses and temperature, per week, at firm B. Feira de Santana, BA, Brazil, 2014.

\begin{tabular}{cccc}
\hline Week & $\begin{array}{c}\text { Number of positive } \\
\text { samples }\end{array}$ & Frequency $(\boldsymbol{\%})$ & Temperature of \\
carcass $\left({ }^{\mathbf{0}} \mathbf{C}\right)$
\end{tabular}


Table 3. Results of microbiological analyses and temperature, per week, at firm C. Feira de Santana, BA, Brazil, 2014.

\begin{tabular}{cccc}
\hline Week & $\begin{array}{c}\text { Number of positive } \\
\text { samples }\end{array}$ & Frequency (\%) & $\begin{array}{c}\text { Temperature of } \\
\text { carcass }(\stackrel{\circ}{ } \mathbf{C})\end{array}$ \\
\hline $\mathbf{1}$ & 1 & 10 & 33.8 \\
$\mathbf{3}$ & 0 & 0 & 35 \\
$\mathbf{4}$ & 1 & 10 & 35.8 \\
$\mathbf{5}$ & 1 & 10 & 34.1 \\
$\mathbf{6}$ & 0 & 0 & 31.3 \\
$\mathbf{7}$ & 0 & 0 & 32.2 \\
$\mathbf{8}$ & 1 & 10 & 35.6 \\
$\mathbf{9}$ & 1 & 10 & 36 \\
$\mathbf{1 0}$ & 0 & 0 & 34.1 \\
Total & 0 & 0 & 31.1 \\
& $\mathbf{5}$ & $\mathbf{5 0}$ & $\mathbf{3 5 . 5}(\mathrm{mean})$ \\
\hline
\end{tabular}


Table 4. Results of microbiological analyses and temperature, per week, at firm D. Feira de Santana, BA, Brazil, 2014.

\begin{tabular}{cccc}
\hline Week & $\begin{array}{c}\text { Number of positive } \\
\text { samples }\end{array}$ & Frequency (\%) & $\begin{array}{c}\text { Temperature of } \\
\text { carcass }\left({ }^{\circ} \mathrm{C}\right)\end{array}$ \\
\hline $\mathbf{1}$ & 0 & 0 & 33.3 \\
$\mathbf{3}$ & 0 & 0 & 30 \\
$\mathbf{4}$ & 0 & 0 & 36 \\
$\mathbf{5}$ & 0 & 0 & 32 \\
$\mathbf{6}$ & 0 & 0 & 32 \\
$\mathbf{7}$ & 0 & 0 & 36 \\
$\mathbf{8}$ & 0 & 0 & 32.2 \\
$\mathbf{9}$ & 0 & 0 & 33.7 \\
$\mathbf{1 0}$ & 0 & 0 & 34.9 \\
Total & 0 & 0 & 35.3 \\
& 0 & 0 & $\mathbf{3 3 . 2}$ (mean) \\
\hline
\end{tabular}

Table 5. Results of microbiological analyses and temperature, per week, at firm E. Feira de Santana, BA, Brazil, 2014.

\begin{tabular}{cccc}
\hline Week & $\begin{array}{c}\text { Number of } \\
\text { positive samples }\end{array}$ & Frequency (\%) & $\begin{array}{c}\text { Temperature of } \\
\text { carcass }(\stackrel{\circ}{ } \mathrm{C})\end{array}$ \\
\hline $\mathbf{1}$ & 0 & 0 & 36.5 \\
$\mathbf{3}$ & 0 & 0 & 31.4 \\
$\mathbf{4}$ & 0 & 0 & 34.3 \\
$\mathbf{5}$ & 0 & 0 & 32 \\
$\mathbf{6}$ & 0 & 0 & 34 \\
$\mathbf{7}$ & 0 & 0 & 31.1 \\
$\mathbf{8}$ & 0 & 0 & 35 \\
$\mathbf{9}$ & 0 & 10 & 32.2 \\
$\mathbf{1 0}$ & 0 & 0 & 34.5 \\
Total & 0 & 0 & 32.2 \\
\hline
\end{tabular}


Table 6. Results of microbiological analyses and temperature, per week, at firm F. Feira de Santana, BA, Brazil, 2014.

\begin{tabular}{|c|c|c|c|}
\hline Week & $\begin{array}{r}\text { Number of } \\
\text { positive samples }\end{array}$ & Frequency (\%) & $\begin{array}{l}\text { Temperature of carcass } \\
\left({ }^{\circ} \mathrm{C}\right)\end{array}$ \\
\hline 1 & 0 & 0 & 31 \\
\hline 2 & 0 & 0 & 30.5 \\
\hline 3 & 1 & 10 & 34 \\
\hline 4 & 0 & 0 & 34 \\
\hline 5 & 0 & 0 & 35 \\
\hline 6 & 0 & 0 & 30.1 \\
\hline 7 & 0 & 0 & 38.4 \\
\hline 8 & 0 & 0 & 33.8 \\
\hline 9 & 0 & 0 & 35.7 \\
\hline 10 & 0 & 0 & 32 \\
\hline Total & 1 & 10 & 33.2(mean) \\
\hline
\end{tabular}

Current investigation underscored the diagnosis of Salmonella Enteritidis and S.Typhimurium in the samples. However, the two species were not identified in any group, even though Salmonella sp. was extant as a genus where its presence occurred in all the groups, as Tables 1 to 7 demonstrated.
The above fact probably suggests other species of Salmonella, similar to those reported by Hofer et al. (1997), who, in their studies on serovars of Salmonella isolated from poultry in Brazil, registered Salmonella gallinarum, Salmonella pullorum, Salmonella Heidelberg and Salmonella Infantis, besides Salmonella 
Enteritidis and Salmonella Typhimurium.

Increase of sporadic cases and outbreaks of human salmonellosis in several countries is related to the increase of infection by Salmonella due to the intake of poultry meat, eggs and other contaminated derived products. Several studies show that the occurrence of Salmonella spp. in broiler carcasses may vary between $0.024 \%$ and $85.0 \%$. It is actually an important transmission vehicle of the bacterium (ALOCCER et al., 2006).

Table 7. Frequency of positive samples/week. Feira de Santana BA Brazil, 2014.

\section{COMMERCIAL FIRMS}

\begin{tabular}{ccccccc}
\hline Week & $\mathrm{A}$ & $\mathrm{B}$ & $\mathrm{C}$ & $\mathrm{D}$ & $\mathrm{E}$ & $\mathrm{F}$ \\
\hline $\mathbf{1}$ & 0 & 100 & 100 & 0 & 0 & 0 \\
$\mathbf{3}$ & 100 & 0 & 0 & 0 & 0 & 0 \\
$\mathbf{4}$ & 0 & 0 & 100 & 0 & 0 & 100 \\
$\mathbf{5}$ & 0 & 0 & 100 & 0 & 0 & 0 \\
$\mathbf{6}$ & 100 & 0 & 0 & 0 & 0 & 0 \\
$\mathbf{7}$ & 100 & 0 & 0 & 0 & 0 & 0 \\
$\mathbf{8}$ & 0 & 100 & 100 & 0 & 0 & 0 \\
$\mathbf{9}$ & 100 & 100 & 100 & 0 & 100 & 0 \\
$\mathbf{1 0}$ & 100 & 0 & 0 & 0 & 0 & 0 \\
Mean(\%) & $\mathbf{6 0}$ & $\mathbf{4 0}$ & $\mathbf{5 0}$ & $\mathbf{0}$ & $\mathbf{1 0}$ & $\mathbf{1 0}$ \\
\hline
\end{tabular}

Studies by Sakugawa et al. (2008) revealed that Salmonella spp. $(71.7 \%)$, E. coli $(95 \%)$ and S. aureus $(43.35 \%)$ were extant in samples on the retail market of
João Pessoa PB Brazil. Although quality is underscored, several species of Salmonella are present in broilers' meat sold on the market. 
Current analysis provides visibility on the occurrence of Salmonella sp. in poultry products (carcass of whole broilers) sold in Feira de Santana BA Brazil, or rather, precisely the products derived from illegal abattoirs with no official sanitary certificate on commercialization. This boils down to the fact that the origin, production methods and hygiene processes are unclear.

Tables 1, 2, 3, 4, 5, and 6 clearly demonstrate that temperatures of all the broilers' carcasses from all the firms did not meet the standards demanded by current legislation during the ten week in which these conditions were investigated. The above is of great concern since the carcasses with such temperature are prone to the growth of mesophyll microorganisms (high rates of deteriorating and pathogenic micro-organisms) at a best growth temperature between 25 and $40^{\circ} \mathrm{C}$. It should be emphasized that the best temperature for the growth of most pathogenic bacteria, among which may be mentioned Salmonella sp., is approximately $37^{\circ} \mathrm{C}$ (JAY, 2005).

Therefore, the consumer of such poultry meat is exposed to high biological risk. Results of the microbiological analysis of the commercial firms A, B, C, $\mathrm{E}$ and $\mathrm{F}$, respectively provided in Tables 1, 2, 3, 5 and 6, definitely co-relate them to the origin of the slaughtered animals, the possibility of cross-contamination during slaughter and meat processing and exposure to poor storage and conservation conditions

Similar storage conditions were evidenced in all the commercial firms under analysis. All the meat products were exposed on tables without any temperature control and, therefore, subjected to oscillations in room temperature. No specific refrigeration or otherwise was detected in any commercial firm that would maintain the temperature of the meat products under control. Commercial firms must comply with Law 304 published in 1996 in the base of beef and 
pork, or rather, in the case of cattle and swine abattoirs they must deliver only cooled meat and offal for retail at a temperature up to $7^{\circ} \mathrm{C}$, and commercial firms must maintain such temperature (BRASIL, 1996). It is actually a highly relevant factor since meat products should not be let to deteriorate due to inadequate handling within the distribution chain, which may be in fact evidenced during transport and unloading at the selling depot (BRASIL, 1996). In the case of poultry meat, the technical regulation for technological inspection is provided by Law 210 (BRASIL, 1996) which underscores two conservation methods, namely, the temperatures and the procedures that abattoirs and commercial firms should comply with. Law 210 deals with the conservation methods by cooling, or rather, the process of refrigeration and maintenance of temperature between $0^{\circ} \mathrm{C}$ and $4^{\circ} \mathrm{C}$ in the case of poultry meat (carcasses, cuts, offal and other derived products), with a tolerance of $1^{\circ} \mathrm{C}$, measured within the interior of the products. It also deals with the freezing process and the maintenance of a temperature not higher than $-12^{\circ} \mathrm{C}$ for poultry products (carcasses, cuts, offal and other derived products), with a tolerance of up to $2^{\circ} \mathrm{C}$, measured within the interior of the products (BRASIL, 1996). The results from Firm D, reported in Table 4, reinforce a monitoring process. In spite of the adverse conditions mentioned above, there was a $0 \%$ frequency for Salmonella sp., although this fact may be co-related to the occurrence of the pathogen at the poultry origin and not to storage conditions.

When all the samples in all the commercial firms have been analyzed, it may be evidenced that 17 samples were positive for Salmonella sp.

The contaminated samples amounted to $28 \%$ frequency for all the samples evaluated. Microbiological analyses revealed a higher number of positive samples in commercial firm A, with $35 \%$, followed by C with $29 \%$, B with $24 \%$, E 
and $\mathrm{F}$ with $6 \%$ each and $\mathrm{D}$ without any contamination. Figure 1 shows the results.

Maldonado (2008) identified the percentage of bacteria in carcasses and offal of cooled broilers sold in fairs and in a municipal market in the western region of São Paulo SP Brazil, in May 2007, featuring a high index of Salmonella.

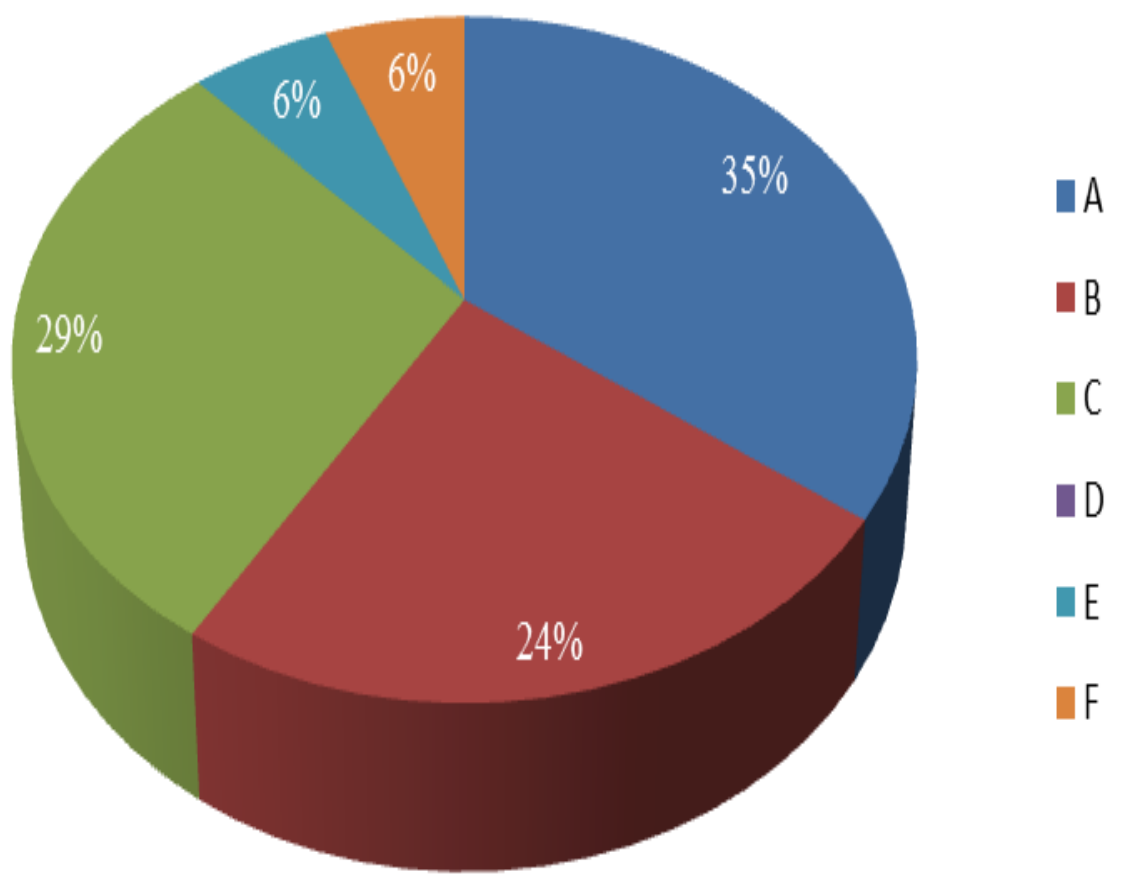

Figure 1. Frequency of total positive samples per commercial firm. Feira de Santana, BA, Brazil, 2014.

During the period mentioned above, 75 samples were analyzed, of which $65 \%$ were contaminated with some species of bacteria and $35 \%$ by Salmonella.

Another investigation by Silva et al. (2006) showed that in a samples of 60 birds sold in commercial firms and in open fairs in the western region of São Paulo SP Brazil, approximately $40 \%$ of the poultry were positive to Salmonella spp.

Figure 2 demonstrates the percentages of positive samples detected during the 10 
weeks, taking into account the ten weeks of repetition. Highest frequency occurred on weeks $1,3,7$ and 9 within the interval proposed.

According to Silva et al. (2006), Salmonella spp. is redundant in wild poultry breeding when compared to poultry in breeding houses. This fact may be corroborated by research in granges in the northern region of the state of Paraná, Brazil and in a poultry abattoir in Jacarezinho PR Brazil.

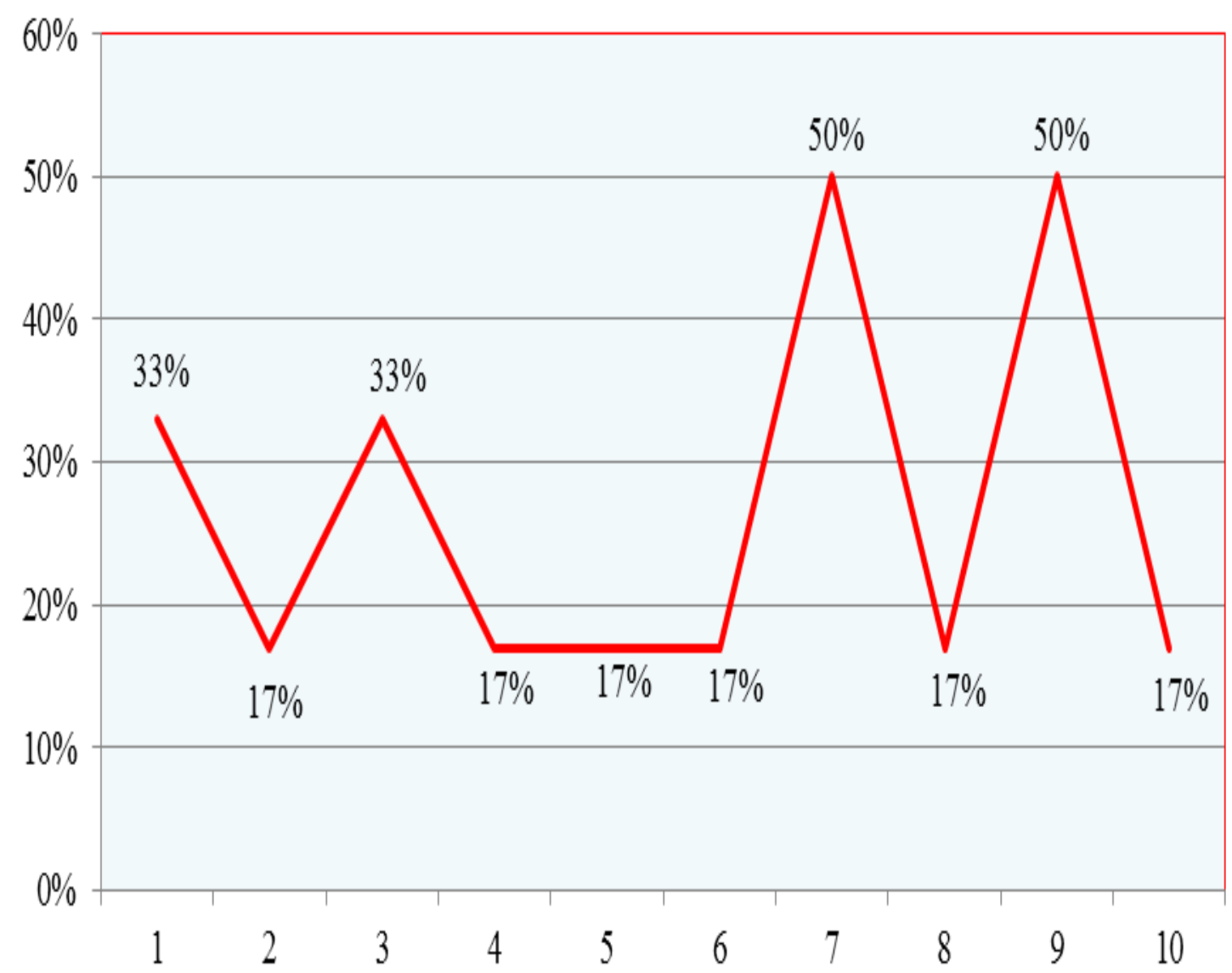

Figure 2. Frequency of positive samples throughout the period (weeks). Feira de Santana, BA, Brazil, 2014.

According to Silva (2014), Silva \& for public health due to exposure to Duarte (2006) and SILVA et al. (2006), infectious and parasite agents transmitted illegal poultry slaughter is a high concern to humans by animals in the intake of 
quality-lacking food and by environmental contamination. The unknown origin of animals and breeding methods place impediments and challenges on the monitoring process and exposes workers to zoonosis.

It should be underscored that illegal poultry slaughter is a crime against consumers, which must be hindered by all means by the health authorities. The dissemination of activities based on sanitary education by the conscienceawareness of consumers in all the social classes should be underscored.

Food in general, especially from animal origin, such as meat, eggs and milk, is the receiving end of many bacteria, resulting in Food-Borne Diseases (FBD). Maldonado (2008) reports that the inherent characteristics favor the presence and multiplication of bacteria, collaborated by the occurrence of FBDs with the intake of such food.

Salmonella is one of these microorganisms in products of animal origin, such as cattle, swine and poultry, which contribute heavily in the contamination of humans, with a subsequent issue for public health, even in developed countries which are also responsible for FBDs. According to Maldonado (2008), FBDs, especially those caused by Salmonella spp., currently represent one of the main concerns of health authorities due to the difficulty in controlling the production chain and in accessing the number of people affected by the pathogen.

In the case of meat control, the biosafety process should start during breeding where control should be drastically undertaken.

According to Maldonado (2008), Salmonella in poultry breeding without aiming any type of industrialization is rife due to the absolute lack of control and quality.

As has been remarked by Tiroly \& Costa (2006), "in Brazil, the occurrence of Salmonella is relevant due to deficiencies 
in basic health conditions and to bad hygiene and sanitary conditions in most of the population, coupled to poor quality control of certain food industries and of small poultry abattoirs".

So that a better control of pathogens detected in samples from the commercial firms mentioned above, a monitoring process in the production chain should be established by research on the site of slaughtering process up to poultry breeding houses.

\section{Conclusion}

When all aspects are taken into account, it becomes evident that the occurrence of Salmonella sp. in food products is a great health risk for consumers.

Although the micro-organism has not been detected in all the samples and in all the commercial firms evaluated, the existence of other pathogenic microorganisms should also be taken into account due to the inadequate hygiene conditions and conservation provided by the products under analysis.

Poultry-origin products, such as meat and eggs and other derivate products contaminated by the pathogens, are a potential risk for the occurrence of human salmonellosis.

Contamination risk by the pathogen is very high in products from illegal slaughter houses due to the lack of information on the product, or rather, its origin, the breeding method, slaughter and meatprocessing methods, information of hygiene condition in the processing.

It should be underlined that the commercialization of products from illegal slaughter is evident and that the demand of the product and its clients are extant. The factors that justify such selling may be foregrounded on economic, social and cultural bases.

Brazilian society at all levels should be aware of the existence of illegal slaughtering houses and the problem that 
this ensues, especially the exposure of the population to inherent biological risks, such as Salmonella spp. The risks involve the producer and the consumer.

\section{References}

ALOCCER, I., OLIVEIRA, M. P., VIDOTTO, M. C., OLIVEIRA, T. C. R. M., 2006. Discriminação de sorovares de Salmonella spp. isolados de carcaças de frango por REP e ERIC-PCR e fagotipagem do sorovar Enteriditis. Ciência e Tecnologia de Alimentos 26 (2), 414-420.

BARROW, P. A., 1993. Salmonella present, past and future. Avian Pathology 22, 651-669.
BRASIL, 1996. Portaria n 304 de 22 de abril de 1996. Estabelecimentos de abate de bovinos, bubalinos e suínos, somente poderão entregar carnes e miúdos, para comercialização, com temperatura de até 7 (sete) graus centígrados. Diário Oficial [da] República Federativa do Brasil, Brasília, DF. Ministério da Agricultura, Pecuária e Abastecimento.

BRASIL, 2001. Instrução normativa $n^{\circ} 70$ de 06 de outubro de 2001. Programa de redução de patógenos. Diário Oficial [da] República Federativa do Brasil, Brasília, DF. Ministério da Agricultura, Pecuária e Abastecimento. 
BRASIL, 2003. Instrução normativa $n^{\circ} 62$ de 26 de agosto de 2003. Métodos Analíticos Oficiais para Análises Microbiológicas para Controle de Produtos de Origem Animal e Água. Diário Oficial [da] República Federativa do Brasil, Brasília, DF. Ministério da Agricultura, Pecuária e Abastecimento.

BOER, E., ZEE, H. V., 1992. Salmonella in foods of animal origin in the Netherlands, p. 265-271. In: Salmonella and Salmonellosis Symposium, Ploufragan, França.

COSTA, F. N., 1996. Sorotipos de Salmonella em carcaças e cortes de frango obtidos na indústria e no comércio e comportamento das cepas isoladas frente à ação de antimicrobianos. 1996. Master'S Dissertation in Preventive Veterinary Medicine - Faculdade de Ciências Agrárias e Veterinárias da UNESP, Jaboticabal SP Brazil.
GIESSEN, A. W., DUFRENNE, J. B., RITMEESTER, W. S., BERKERS, P. A. T. A., LEEUWEN, W. J., NOTERMANS, S. H. W., 1992. The identification of Salmonella enteritidis-infected poultry flocks associated with an outbreak of human salmonellosis. Epidemiology and Infection, 109, 405-411.

HOFER, E., SILVA FILHO, S. J., REIS, E. M. F., 1997. Prevalência de sorovares de Salmonella isolados de aves no Brasil. Pesquisa Veterinária Brasileira, 17 (2), $55-62$.

JAY, J. M., 2005. Microbiologia de Alimentos. Livraria Artmed, $6^{\mathrm{a}}$ Ed., 462464.

MALDONADO, A., 2008. Ocorrência de Salmonela spp. em carcaças e miúdos de frangos abatidos em feiras livres na zona oeste da cidade de São Paulo. Dissertação (Master's in Experimental Epidemiology applied to Zoonosis) - Faculdade de 
Medicina Veterinária da Universidade de

São Paulo SP Brazil. Available at http://www.usp.com.br/dissertação/zootecn ia on $30 / 02 / 2010$.

NAGARAJA, K. V., POMEROY, B. S., WILliaMS J. E., 1991. Paratyphoid infections, 99-130. In: CALNEK et al. (eds.) Diseases of Poultry. 9th ed. Iowa State University Press, Ames, USA.

POPPE, C., 1994. Salmonella Enteritidis in Canada. International Journal of Food Microbiology, 21, 1-5.

RAMPLING, A., UPSON, R., PETERS, E., ANDERSON, J. R., WARD, L. R., ROWE B., 1989. Salmonella enteritidis phage type 4 infection of broiler chickens: a hazard to public health. Lancet, 14, 436438.
RODRIGUE， D. C., TAUXE， R. V., ROWE B., 1990. International increase in Salmonella enteritidis: a new pandemic? Epidemiology and Infection, 105, 21-27.

TAVECHIO, A. T., FERNANDES, S. A., NEVES, B. C., DIAS, A. M. G., IRINO, K., 1996. Changing patterns of Salmonella serovars: increase of Salmonella Enteritidis in São Paulo, Brazil. Revista do Instituto de Medicina Tropical, 38 (5), 315-332.

SAKAI, T., CHALERMCHAIKIT, T., 1996. The major sources of Salmonella Enteritidis in Thailand. International Journal of Food Microbiology, 31, 173180. 
SAKUGAWA, N. K., BARROS, V. B., MACHADO, I. C. L., FILHO, J. L. L., 2008. Salmonella spp., importante agente patogênico veiculado em alimentos.

Ciência \& Saúde Coletiva, 13 (5), 16691674.

SANTOS, D. M. S., BERCHIERI

JUNIOR, A., FERNANDES, S. A., TAVECHIO, A. T., AMARAL, L. A., 2000.

Salmonella em carcaças de frango congeladas. Pesquisa Veterinária Brasileira, 20 (1), 39-42.

SCUDERI, G., FANTASIA, M., FILETICI, E., ANASTASIO, M. P., 1996. Foodborne outbreaks caused by salmonella in Italy, 1991-1994. Epidemiology and Infection, $116,257-265$.
SILVA, W., 2014. O abate clandestino: avanços e desafios na Bahia. BEEFPOINT. At http://www.beefpoint.com.br/cadeiaprodutiva/espaco-aberto/o-abateclandestino-avancos-e-desafios-na-bahia44560 on $10 / 01 / 2014$.

SILVA, E., DUARTE, T., 2006. Salmonela Enteritidis em Aves: Retrospectiva no Brasil. Revista Brasileira de Ciência Avícola, 4(2), 85-100.

SILVA, A. C., JÚNIOR, A., SOUZA, E., WERTHER, K., 2006. Pesquisa de Salmonella spp. em instalações avícolas selvagens. Revista do Instituto de Medicina Tropical de São Paulo, 38 (5), 315. 
TIROLY, I. C. C., COSTA, C. A., 2006. WARD, L.R., THRELFALL, E. J., 1997. Incidência de Salmonella spp. em carcaças Human salmonellosis in England and de frangos recém abatidos em feiras e Wales - current situation, p. 547-9. In: mercados da cidade de Manaus- AM. Salmonella and Salmonellosis Revista Acta Amazônia, 36 (2), 205-208. $\quad$ Symposium, Ploufragan, França. 